\title{
Pemanfaatan E-learning untuk Latihan Kanji dan Tata Bahasa Jepang untuk Tingkat Menengah
}

\author{
Vera Yulianti \\ Program Studi Sastra Jepang, Fakultas Sastra \\ Universitas Al Azhar Indonesia, Jl. Sisingamangaraja, Jakarta 12110 \\ Penulis untuk korespondensi/E-mail: vera.yulianti@uai.ac.id
}

\begin{abstract}
Abstrak - Seiring dengan meningkatnya tingkatan pembelajaran bahasa Jepang, diperlukan sarana latihan yang dapat menunjang kemandirian proses belajar. Tujuan penelitian ini adalah mengevaluasi pemanfaatan e-learning unutk latihan Tata Bahasa Jepang dan Kanji tingkat menengah . Metode penelitian adalah metode tindakan kelas dengan menggunakan alat ukur tes awal dan tes akhir serta angket skala likert 5 mengenai kepuasan pembelajar tentang penggunaan e-learning untuk latihan kanji dan tata bahasa Jepang. Hasil penelitian menunjukkan bahwa penggunaan e-learning untuk latihan menunjukkan pengaruh yang positif pada prestasi belajar pembelajar, membantu penguasaan pemahaman dasar dasa Kanji yang sedang dipelajari dan membantu kemandirian pembelajar dalam mengembangkan kemampuan Tata Bahasa dan Kanji tingkat menengah.
\end{abstract}

Kata kunci-e-learning, tata bahasa Jepang, Kanji bahasa Jepang, latihan, proses belajar mandiri

Abstract - While the learner's level becoming higher, there is a need of exercise media which support autonomous learning process. Therefore, the aim of this study is to evaluate the effectiveness of using $e$ learning as media for exercising Intermediate Kanji and Japaense Grammar. The Method of this study is action research using pre test, post test and 5 likert scale questionnaire to investigate the effectiveness of using e-learning. The results show using e-learning as a media for exercising intermediate Kanji and Japanese grammar gives positive effect to the learner's study result, improves the learner's understanding of basic Kanji knowledges itself and helps the learners of developing the autonomous o learning process.

Keywords - e-learning, japanese grammar, japanese kanji, exercise, autonomus learning process

\section{PENDAHULUAN}

$S$ eiring dengan makin meningkatnya tahapan pembelajaran bahasa asing seorang pembelajar, maka kemandirian untuk meningkatkan kemampuan tersebut juga lebih dituntut. Proses pembelajaran yang mengacu kepada proses pembelajaran Student Centered Learning (SCL) akan sangat membantu mempercepat meningkatkan kemampuan belajar bahasa asing seseorang. Demikian pula dalam proses pembelajaran bahasa Jepang.

Dalam proses pembelajaran bahasa Jepang, untuk meningkatkan empat kemampuann berbahasa (berbicara, menyimak, membaca dan menulis) Jepang, khususnya untuk membaca dan menulis, kemandirian untuk penguasaan huruf kanji dan beragam tata bahasa sangat dituntut. Target jumlah kanji yang harus dikuasai dalam satu semester (kurang lebih sekitar 150 kanji) tidak dapat semuanya diajarkan dan dilatihkan di dalam kelas. Kendala jumlah jam belajar di dalam kelas membuat proses latihan dalam jumlah waktu yang cukup menjadi sulit. Keinginan untuk menjadikan proses belajar tata bahasa dan kanji menjadi jam belajar yang terpadu dalam satu pertemuan selama 100 menit, membuat pengajar kesulitan untuk mengatur waktu agar selama satu pertemuan tersebut tidak hanya menjadi proses pemahaman materi baru saja, akan tetapi juga terdapat cukup waktu untuk latihan penerapan baik untuk materi yang sudah dipelajari maupun materi baru.

Di lain sisi, seiring dengan . Target jumlah kanji yang harus dikuasai dalam satu semester ( kurang 
lebih sekitar 150 kanji ) tidak dapat semuanya diajarkan dan dilatihkan di dalam kelas., sejak tahun 80-an pengaruh penggunaan media ICT dalam dunia pendidikan bahasa makin meluas, terutama untuk pengajaran bahasa secara interaktif. Pada masa sekarang, media ICT tidak hanya digunakan untuk membuat sumber belajar ( learning resources) tapi juga ICT sebagai alat komunikasi online dalam proses pembelajaran bahasa asing ( Regine Hampel, 2010 dalam Michael Thomas \& Hayo Reinders, 2010 : 131). Demikian pula penggunaan web-based social media pada masa kini memberikan tantangan dan peluang bagi dunia pendidikan bahasa untuk makin berkembang (Michael Thomas \& Hayo Reinders , 2010:6).

Di Indonesia sendiri pada masa kini ICT mengalami perkembangan yang sangat pesat. Jika pada kurun waktu beberapa tahun yang lalu sangat sulit untuk memperoleh akses ke dunia maya, seiring dengan perkembangan teknologi telepon genggam (handphone) sebagai salah satu media $I C T$, akses ke dunia maya menjadi lebih mudah. Dengan harga telepon genggam yang semakin relatif murah dibandingkan dengan teknologi yang dimilikinya, jumlah pengguna telepon genggam semakin meningkat dan akses ke dunia maya semakin lebih mudah.

Dengan mempertimbangkan masalah kendala waktu pembelajaran di dalam kelas, namun di lain sisi perkenbangan ICT yang sangat pesat termasuk di Indonesia, perlu dipertimbangkan sebuah upaya untuk memanfaatkan ICT untuk memenuhi kebutuhan latihan kanji dan tata bahasa Jepang tingkat menengah yang tidak dapat dipenuhi di dalam kelas. Untuk itu, perlu dilakukan penelitian untuk melihat efektifitas pemanfaatan e-learning untuk latihan kanji dan tata bahasa Jepang tingkat menengah.

Tujuan penelitian ini adalah untuk menganalisis efektifitas pemanfaatan e-learning untuk latihan kanji dan tata bahasa Jepang tingkat menengah. Kelebihan dan kekurangan apa saja yang dihadapi baik oleh pembelajar maupun pengajar ketika memanfaatkan e-learning untuk keperluan tersebut, sehingga pemanfaatannnya lebih dapat dioptimalkan dan kekurangannnya dapat diantisipasi.

\section{LANDASAN TEORI}

\section{Pembelajaran yang Berpusat pada Siswa (Student-Centered Learning)}

Menurut Collins dan O'Brien (2003) dalam Jeffrey Froyd dan Nancy Simpson (2010:2) mengenai pengertian pembelajaran berpusat pada Siswa (Student-Centered Learning) atau Pembelajaran yang Berpusat pada Siswa (dalam tulisan ini selanjutnya disebut PBS) ialah sebuah cara mengajar dengan menempatkan murid atau pembelajar sebagai pusat dari proses pembelajaran [1]. Jika pada proses belajar pada umumnya, pengajar menyiapkan hingga mengatur jalannya sebuah alur pengajaran dalam kelas, maka cara PBS ini memberikan kesempatan pada pembelajar untuk dapat lebih belajar secara mandiri ataupun belajar dari sesama teman mereka sesuai dengan materi yang telah disajikan pengajar.

Berbeda dengan teacher-centered learning, pendekatan PBS menitikberatkan pada peran terbuka pembelajar selama pelajaran berlangsung, apakah itu penentuan sebuah pembahasan tertentu, bagaimana permasalahan yang mungkin timbul, kemudian jalan pemecahan secara kritis atau kreatif dengan melibatkan pembelajar dalam cara belajar mandiri ataupun dengan cara belajar berkelompok. Meskipun PBS lebih ditekankan dari sisi peranan para pembelajar, peran pengajar tidak dapat dikesampingkan. Masing-masing pembelajar tentunya mempunyai pemikiran serta ide tersendiri terkait sebuah pokok bahasan yang dikemukakan dalam kelas, sehingga terkadang alur proses pembelajaran yang pada awalnya telah dipersiapkan oleh pengajar cenderung meluas ataupun bahkan melenceng dari pokok bahasan awal.

Oleh karena itu, peran pengajar dibutuhkan guna mengontrol keseimbangan jalannya pelajaran. Contohnya dalam hal umpan balik perbaikan kesalahan (corrective feedback). Penerapan metode PBS yang tepat dari pengajar diharapkan dapat mendorong siswa untuk bersikap lebih aktif dalam kelas agar berwawasan lebih luas terhadap materi yang dipelajari.

Selain pendapat di atas, pendapat mengenai pembelajaran yang berpusat pada siswa (Student Centered Learning) dikemukakan oleh Leo Jones. Dalam tulisannya yang bertajuk The StudentCentered Classroom, Leo Jones (2007:2) membahas secara mendetail mengenai metode PBS ini bahwa dalam kelas dengan sistem PBS para 
siswanya tidak tergantung sepenuhnya kepada guru, seperti menunggu instruksi atau koreksi, meminta persetujuan, atau bahkan pujian [2]. Dalam hal ini, posisi pengajar hanya sebagai mediator yang bertugas mengarahkan siswa, agar siswa menemukan jawabannya dengan mencari sendiri ataupun memperolehnya dengan berkomunikasi antar sesama siswa.

\section{Pembelajaran Tata Bahasa Melalui E-learning}

Shinozaki ( 2011) meneliti pemanfaatan e-learning untuk pembelajarana Tata Bahasa tingkat lanjut pada kelas bahasa Jepang untuk mahasiswa asing di Beppu University [3]. Hasil dari penelitian tersebut lebih dari $70 \%$ responden menyatakan terbantu dalam penguasaan tata bahasa melalui pembelajaran e-learning berbasis aplikasi Moodle dan hasil tes menunjuukkan $63,4 \%$ hasil meningkat. Hal yang perlu diantisipasi dari penelitian ini adalah memikirkan agar konten materi mengacu ke Japanese Language Proficiency Test ( JLPT ) agar hasil belajar bersifat standar Internasional pembelajaran bahasa Jepang.

\section{METODE PENELITIAN DAN TEKNIK PENGUMPULAN DATA}

\section{Metode Penelitian}

Metode yang digunakan adalah penelitian tindakan kelas dengan menggunakan angket likert skala 5 untuk mengevaluasi pendapat responden mengenai pemanfaatan e-learning untuk latihan kanji dan tata bahasa Jepang tingkat menengah. Selain itu, hasil Ujian tengah Semester ( UTS ) dan Ujian Akhir Semester ( UAS ) akan dibandingkan untuk melihat apakah ada peningkatan prestasi belajar setelah mengggunakan e-learning sebagai media belajar Kanji dan Tata Bahasa.

Untuk memastikan apakah ada peningkatan prestasi dengan penggunaan e-learning meningkatkan kemandirian pembelajaran Kanji dan Tata Bahasa tingkat menengah, proses pembelajaran dari awal semester hingga tengah semester ( sebelum UTS ) menggunakan metode klasikal yang berpusat pada pengajar . Responden hanya diminta mempelajari bahan yang akan dibahas di kelas tanpa adanya penugasan terstruktur. Hasil belajar hingga UTS yang ditunjukkan dengan nilai UTS dijadikan sebagai hasil tes awal.

Kemudian, setelah UTS setiap pekan sebelum proses pembelajaran kelas berlangsung responden ditugaskan untuk mengerjakan tugas terstruktur dalam kelompok dengan menggunakan e-learning sebagai media belajar. Untuk memberikan kesempatan pada pembelajar untuk berperan besar dalam proses belajarnya, pengajar hanya menentukan batasan materi kanji dan Tata Bahasa yang harus dipelajari sebelum proses belajar di kelas berlangsung, memberikan alternatif link-link website yang bisa diakses pembelajar sebagai sumber belajar dan membuat tugas terstruktur yang kemudian diunggah di e-learning UAI. Adapun pembagian tugas di dalam kelompok, penentuan website-website sumber belajar yang akan digunakan seperti kamus online dan corpus online yang memuat contoh-contoh penerapan tata bahasa dan kosakata Kanji dalam kalimat, diserahkan pada pembelajar untuk mendiskusikannya di dalam kelompok.

Bahan ajar utama yang digunakan untuk memelajari Kanji tingkat menengah adalah buku ajar Intermediate Kanji volume 1 ( 1993 ) [4] Sedangkan untuk Tata Bahasa tingkat menengah, buku ajar utama yang digunakan adalah New Approach Japanese Intermediate Course ( 2002 ) [5]. Sedangkan website-website yang diberikan kepada pembelajar sebagai alternatif sumber belajar adalah Japanese Learner's Dictionary (http://dictionary.j-cat.org/JtoE/index.php) yang dikembangkan oleh peneliti-peneliti dari Tsukuba University, Online Japanese Dictionary (http://jisho.org/kanji/ ), Online Kanji Dictionary yangn dikembangkan oleh The Yamasa Institute (http://www.yamasa.org/ocjs/kanjidic.nsf/MainPage ?OpenForm ) dan beberapa kamus online lainnya.

Adapun tahapan penugasannya adalah sebagai berikut. Pertama adalah penjelasan tentang tujuan penugasan dan cara melakukan tugas. Kepada responden diperkenalkan tentang SILK ( Strategy Inventory Learning Kanji ) yang memperkenalkan berbagai metode untuk menguasai Kanji melalui pengetahuan dasar-dasar Kanji. Kemudian responden dibagi ke dalam kelompok yang terdiri dari empat orang. Sebelum proses pembelajaran di dalam kelas setiap pekan, masing-masing kelompok ditugaskan untuk mendalami pemahaman dasar tentang Kanji yang akan dipelajari dengan metode yang disukai masingmasing responden yang telah diperkenalkan melalui SILK. Adapun pemaham dasar yang harus dikuasai adalah jumlah coretan Kanji, urutan Kanji, berbagai variasi cara baca Kanji, makna Kanji sebagai huruf tunggal dan makna gabungan Kanji tersebut dengan Kanji lain. Kemudian, dengan menggunakan Tata Bahasa yang telah 
dipelajari sebelumnya dan Kanji gabungan yang akan dipelajari, masing-masing kelompok juga ditugaskan untuk membuat kalimat sebagai penerapan pemahaman tentang Tata Bahasa yang telah dipelajari di kelas sebelumnya dan Kanji yang akan dipelajari di kelas berikutnya.

Pekerjaan tugas ini harus diunggah di e-learning paling lambat empat hari sebelum kelas dimulai. Dua hari kemudian, hasil pekerjaan tersebut yang telah diperiksa pengajar diunggah balik oleh pengajar untuk dipelajari oleh responden. Di dalam kelas, hasil pekerjaan tersebut didiskusikan bersama seluruh responden, setelah sebelumnya diadakan kuis awal. Setelah kuliah berakhir, kembali diadakan kuis akhir yang soalnya sama dengan kuis awal. Dengan penugasan seperti ini melalui e-learning, sedikit demi sedikit masingmasing kelompok mengunggah hasil belajar mandiri mereka tentang pengetahuan dasar masing-masing kanji yang akan dipelajari. Hasil belajar masing-masing kelompok, dapat diakses oleh kelompok lain sehingga antar kelompok dapat saling belajar dari hasil diskusi kelompok lain. Pada akhir semester, untuk menghadapi persiapan UAS mereka dapat menggunakan hasil belajar via e-learning ini sebagai bahan persiapan UAS.

Hasil UAS kemudian dijadikan sebagai hasil tes akhir yang dibandingkan dengan hasil UTS sebagai hasil tes awal untuk melihat apakah ada perubahan hasil belajar yang signifikan setelah menggunakan e-learning sebagai media belajar Kanji dan Tata Bahasa tingkat menengah. Selain itu, kepada pembelajar diberikan angket skala likert 5 untuk mengetahui penilaian responden tentang efektifitas penggunaan e-learning sebagai media latihan Tata Bahasa dan Kanji tingkat menengah. Isi pertanyaan angket adalah sebagai berikut :

1. Apakah media e-learning membantu untuk menguasai pemahaman dasar masing-masing Kanji ( coretan, cara baca, makna, Kanji gabungan dan contoh pemakaian dalam kalimat )

2. Apakah Latihan Tata Bahasa yang telah dipelajari dapat dilakukan dengan efektif melalui pemanfaatan e-learning

3. Apakah umpan balik penugasan dari pengajar melalui e-learning dianggap efektif untuk membantu mempersiapkan diri sebelum belajar di kelas

4. Apakah media e-learning mempermudah komunikasi proses belajar dengan pengajar, pembelajar lain satu kelompok dan pembelajar lain kelompok

5. Apakah media e-learning meningkatkan kemandirian belajar

6. Manfaat apakah yang dirasakan dengan menggunakan media e-learning untuk latihan Tata Bahasa dan Kanji tingkat Menengah ( jawaban terbuka )

7. Kendala-kendala apa yang dihadapi ketika menggunakan media e-learning ( jawaban terbuka )

Untuk membantu analisis hasil data, juga dilakukan wawancara lanjutan terhadap beberapa orang responden. Materi pertanyaan wawancara lanjutan adalah untuk memastikan jawaban responden pada angket yang telah mereka jawab.

\section{Data / Sumber Data}

Sumber data dalam penelitian ini adalah mahasiswa pembelajar bahasa Jepang Fakultas Sastra Program Studi Sastra Jepang Universitas Al Azhar Indonesia sebanyak 17 orang peserta mata kuliah Kanji- Tata Bahasa Jepang V ( Kanji Bunpou V ) yang juga terdaftar sebagai peserta elearning UAI yang dikembangkan di elearning2@uai.ac.id. Lima orang pembelajar telah belajar selama lima tahun, sedangkan responden lain telah belajar selama tiga tahun. Tidak satupun dari mereka yang pernah tinggal di Jepang. Berdasarkan standar JLPT ( Japanese Language Proficiency Test ), satu orang pembelajar telah memeliki sertifikat N3 ( kemampuan pembelajar menengah ) dan enam belas lainnya memiliki sertifikat N4 ( kemampian pembelajar dasar menengah ).

\section{HASIL ANALISIS}

Hasil pengumpulan data penelitian ini dibagi menjadi dua bagian. Bagian pertama adalah hasil tes awal yang diambil dari hasil Ujian Tengah Semester ( UTS )dan tes akhir yang diambil dari hasil Ujian Akhir Semester ( UAS ). Sedangkan bagian kedua adalah hasil angket mengenai penilaian efektifitas penggunaan media e-learning untuk latihan Tata Bahasa dan Kanji serta hasil wawancara lanjutan.

\section{Hasil Tes Awal ( UTS ) dan Tes Akhir ( UAS )}

Hasil tes awal dan tes akhir yang digunakan untuk melihat apakah terdapat pengaruh signifikan dari penggunaan media e-learning untuk latihan Tata Bahasa dan Kanji tingkat menengah dapat dilihat pada grafik di bawah ini 


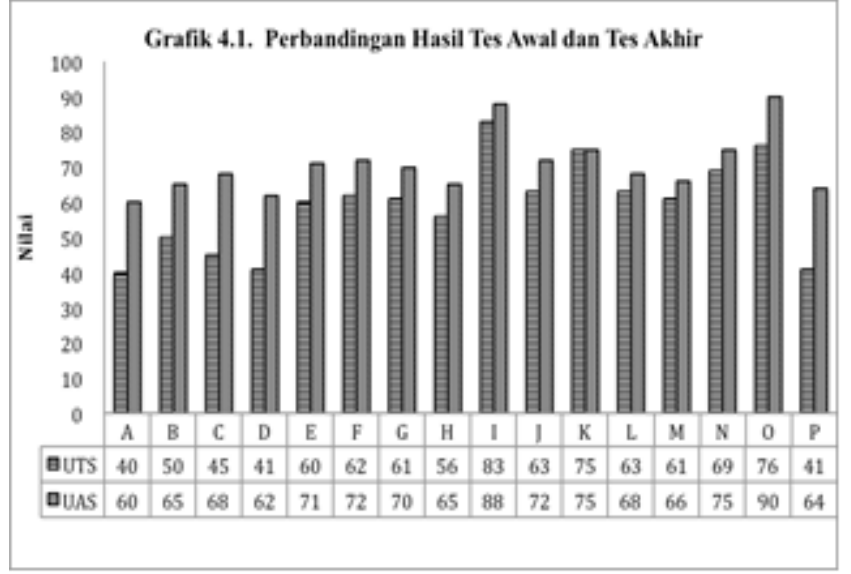

Dari grafik 4.1 dapat dilihat bahwa selain responden $\mathrm{K}$, responden mengalami peningkatan hasil belajar setelah menggunakan media $e$ learning. Pada tes awal , enam orang ( $37,5 \%$ ) responden memperoleh nilai dibawah 60 , tujuh orang ( $43,75 \%$ ) memperoleh nilai $60-70$, dua orang ( $12,5 \%$ ) memperoleh nilai 70-80 dan satu $(6,25 \%)$ orang memperoleh nilai di atas 80 . Sedangkan pada tes akhir, tidak satupun yang memperoleh nilai di bawah 60, delapan orang ( $50 \%$ ) memperoleh nilai 60-70, 6 ( 37,5\% )orang memporoleh nilai 70-80 dan dua orang ( $12,5 \%$ ) yang memperoleh nilai di atas 80 . Secara kelompok nilai, perbandingan nilai tes awal dan tes akhir penelitian ini dapat dilihat pada grafik 4.2 di bawah ini.

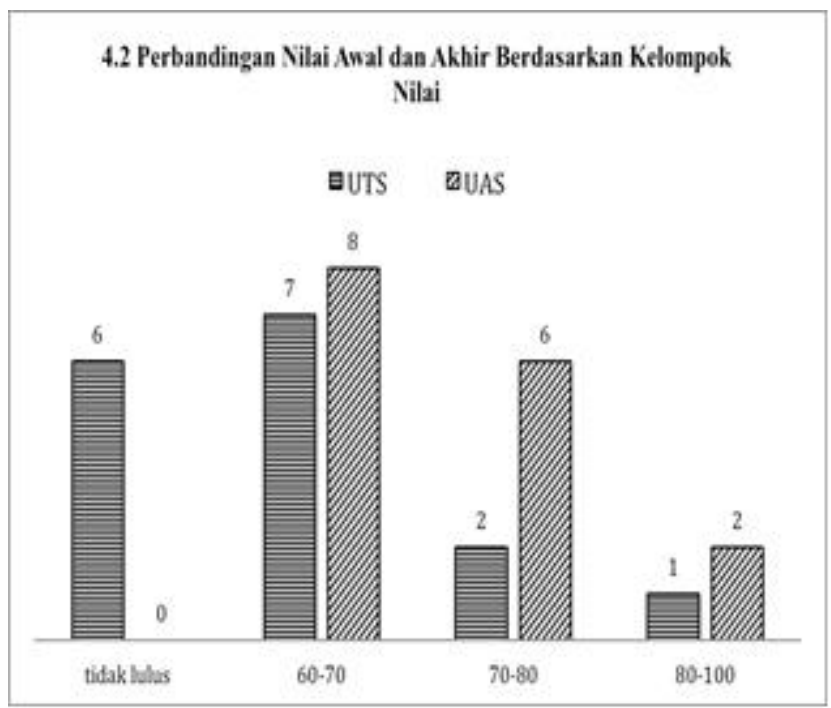

Dari grafik 4.1 dan 4.2 dapat dilihat bahwa terjadi perbaikan hasil belajar dari setelah menggunakan media e-learning sebagai media latihan Tata Bahasa dan Kanji tingkat menengah. Tidak ada satupun yang mendapat nilai di bawah 60 atau tidak lulus. Akan tetapi distribusi perolehan nilai terbeser pada kelompok nilai $\mathrm{C}$, kemudian kelompok nilai
B dan terakhir kelompok nilai A. Setelah materi tes awal dan tes akhir di evaluasi, maka diketahui hal yang mungkin dapat dipikirkan sebagai alasan mengapa peningkatan nilai tidak terlalu signifikan. Pada tes awal materi tes adalah bahan kuliah pertemuan minggu pertama hingga minggu ketujuh yang tidak dipelajari dengan media $e$ learning. Sedangkan materi tes akhir adalah bahan kuliah minggu pertama hingga minggu ke- lima belas, padahal proses belajar dengan media $e$ learning baru dimulai pada pertemuan minggu kesembilan setelah UTS. Dengan demikian ada materi yang tidak dipelajari dengan bantuan media $e$ learning tetapi menjadi materi tes akhir ( UAS ).

Dengan demikian dapat dikatakan bahwa penggunaan media e-learning untuk latihan Tata Bahasa dan Kanji tingkat menengah terbukti memberikan pengaruh pada hasil belajar responden. Pengaruh yang lebih signifikan mungkin akan dapat terlihat jika materi tes akhir hanya mencakup materi-materi yang dipelajari dengan bantuan media e-learning.

\section{Hasil Angket Evaluasi Penggunaan e-learning dan Wawancara Lanjutan}

Hasil angket evaluasi penggunaan e-learning dan wawancara lanjutan akan dibahas satu-persatu sesuai dengan urutan pertanyan pada angket. Analisis hasil angkat dibandingkan dengan jawaban wawancara lanjutan dari beberapa responden terhadap masing-masing pertanyaan.

Pertanyaan pertama adalah apakah media $e$ learning membantu untuk menguasai pemahaman dasar masing-masing Kanji ( coretan, cara baca, makna, Kanji gabungan dan contoh pemakaian dalam kalimat ). Hasil jawaban terhadap pertanyaan pertama dapat dilihat di grafik 4.3 di bawah ini.

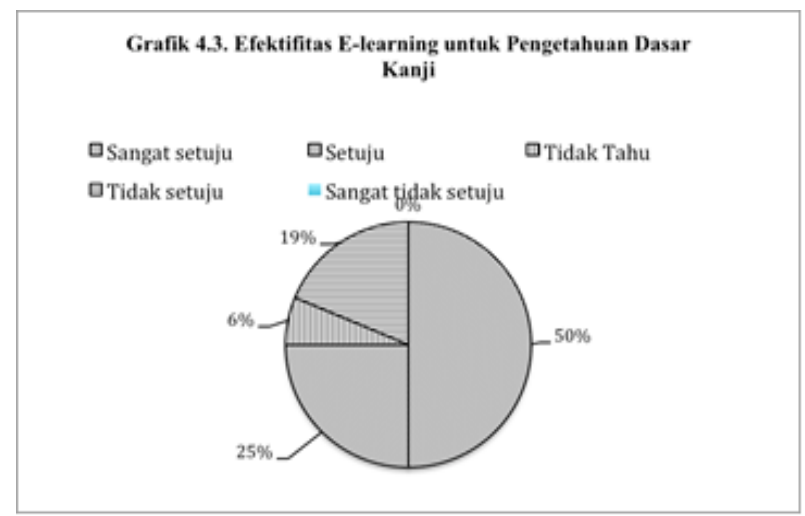

Pada grafik terlihat bahwa 50\% respon menyatakan sangat setuju dan $25 \%$ menyatakan setuju bahwa 
penggunaan media e-learning untuk latihan Tata Bahasa dan Kanji tingkat menengah dinilai efektif untuk membantu menguasai pemahaman dasar tentang setiap Kanji. Melalui media e-learning masing-masing responden bukan hanya mempunyai data base setiap kanji yang telah dipelajarinya secar mandiri, tetapi masing-masing respon juga dapat mempelajari informasi dasar tentang Kanji yang dipelajari dan diunggah ke $e$ learning oleh pembelajar lain. Pada saat wawancara lanjutan, seorang responden yang setuju dengan pertanyaan ini mengatakan bahwa berbagi pemahaman yang dikuasai melalui e-learning seperti ini sangat menghemat waktunya daripada mencari sendiri semuan Kanji yang ditugaskan . Lebih lanjut ia mengatakan bahwa dengan $e$ learning responden dapat saling bekerja sama dengan cara membagi tugas mencari informasi dasar yang harus diketahui dari masing-masing Kanji.

Pertanyaan kedua adalah apakah Latihan Tata Bahasa yang telah dipelajari dan Kanji yang akan dipelajari di dalam kelas dapat dilakukan dengan efektif melalui pemanfaatan e-learning. Hasil jawaban pertanyaan kedua ini dapat dilihat pada grafik 4.4 di bawah ini.

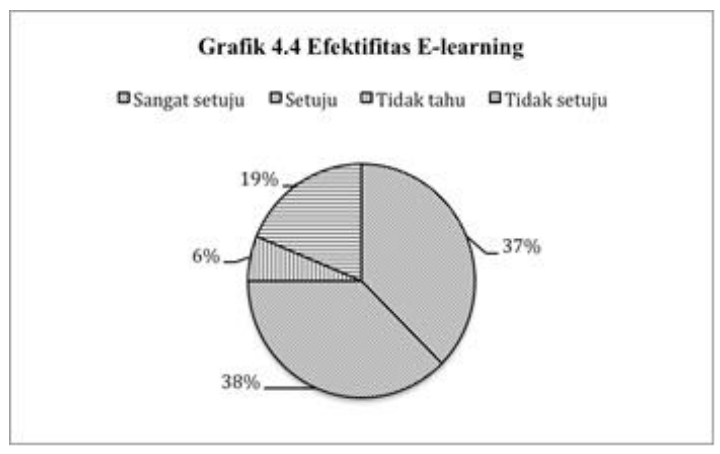

Pada grafik di atas, dapat dilihat bahwa $37 \%$ respon sangat setuju dan $38 \%$ responden setuju bahwa penggunaan media e-learning untuk latihan Tata Bahasa dan Kanji tingkat menengah dinilai efektif. Pada wawancara lanjutan, beberapa responden mengatakan bahwa dengan penugasan terstruktur seperti ini mereka mendapatkan media latihan yang bersifat interaktif sehingga dinilai sangat membantu mempersiapkan diri sebelum mengikuti kuliah.
Pertanyaan ketiga adalah apakah umpan balik penugasan dari pengajar melalui e-learning dianggap efektif untuk membantu mempersiapkan diri sebelum belajar di kelas. Hasil jawaban terhadap pertanyaan ini ditampilkan pada grafik 4.5 di berikut ini.

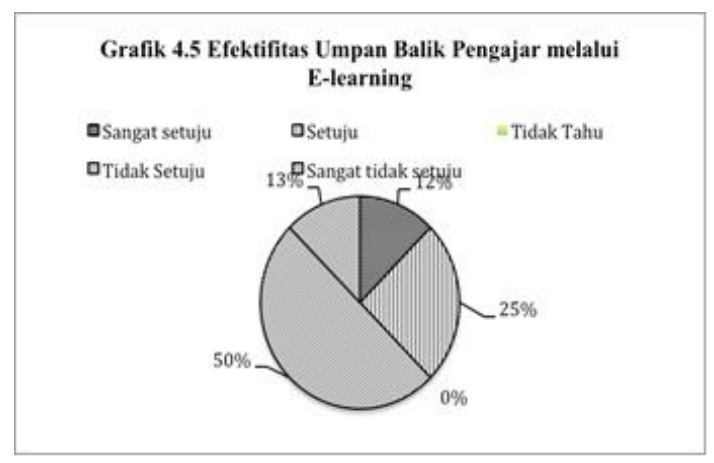

Tidak seperti pada pertanyaan pertama dan kedua, pada pertanyaan ketiga ini responden yang menjawab tidak setuju lebih banyak dari responden yang menjawab setuju. Responden yang menjawab sangat tidak setuju sebanyak $13 \%$ dan responden yang menjawab tidak setuju sebanyak $50 \%$. Artinya ada $63 \%$ responden yang beranggapan bahwa media E-learning dinilai tidak efektif untuk mendapatkan umpan balik dari pengajar dalam latihan Tata Bahasa dan Kanji tingkat menengah. Pada wawancara lanjutan, responden yang menyatakan tidak setuju bahwa media e-learning dinilai efektif untuk mendapatkan umpan balik dari pengajar pada latihan Tata Bahasa dan Kanji menjelaskan bahwa ketika membaca atau mengunduh umpan balik dari pengajar tidak dapat langusng bertanya atau memastikan dikarena pengajar tidak memanfaatkan fasilitas media chatting yang ada pada system e-learning. Pertanyaan baru dapat dilakukan di dalam kelas sesaat sebelum kuis awal dimulai sehingga responen tersebut merasa pada saat mempersiapkan diri untuk kuis awal menjadi kurang maksimal.

Pertanyaan keempat adalah apakah media $e$ learning mempermudah komunikasi proses belajar dengan pengajar, pembelajar lain satu kelompok dan pembelajar lain kelompok. 


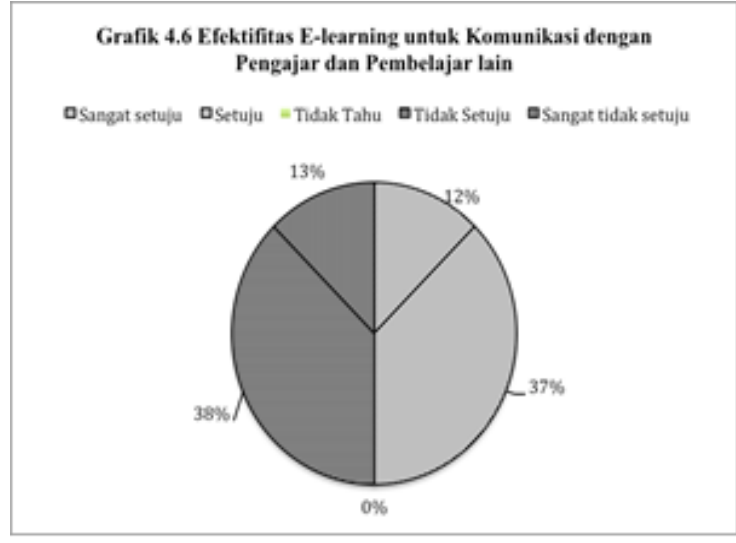

Sama seperti halnya pada jawaban pertanyaaan ketiga, pada pertanyaan keempat, responden yang menjawab tidak setuju lebih banyakdaripada responden yang menjawab setuju. Responden yang menjawab sangat tidak setuju sebanyak $13 \%$ dan responden yang menjawab tidak setuju sebanyak $38 \%$. Artinya ada $51 \%$ responden yang tidak setuju dengan penilaian bahwa media e-learning dinilai efektif sebagai sarana komunikasi antara pengajar dengan pembelajar dan pembelajar dengan pembelajar lain. Pada wawancara lanjutan, responden yan tidak setuju mengatakan alasan yang kurang lebih sama dengan jawaban pertanyaan ketiga. Karena pengajar tidak mengaktifkan fungsi chatting online, pembelajar tidak dapat bertanya langsung khususnya kepada pengajar.

Pertanyaan kelima adalah apakah media e-learning meningkatkan kemandirian belajar. Jawaban terhadap pertanyaan ini dapat dilihat pada grafik 4.7.

Grafik 4.7 Efektifitas E-learing untuk Kemandirian Belajar

OSangat setuju Q Setuju OTidak Tahu DTidak setuju OSangat tidak setuju

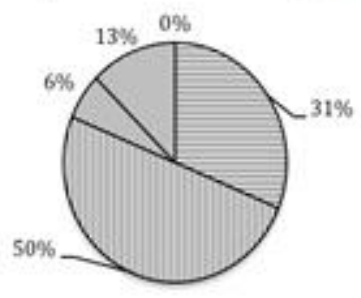

Pada grafik terlihat bahwa $81 \%$ responden setuju mengatakan bahwa secara garis besar, e-learning dapat dinilai efektif untuk mendorong kemandirian belajar responden untuk menguasai Tata Bahasa dan Kanji tingkat menengah. Dengan system online seperti ini, beberapa responden yang diwawancarai mengatakan bahwa media ini dapat menjadi panduan untuk mengembangkan kemampuan Tata Bahasa danKanji tingkat menengah secara mandiri namun tetap terarah karena ada umpan balik dari pengajar meski bersifat ofline atau tertunda di dalam kelas.

Selain pertanyaan angket skala likert 5, kepada responden diberikan dua pertanyaan yang jawabannya bersifat terbuka. Pertama adalah manfaat lain apakah yang dirasakan dengan menggunakan media e-learning untuk latihan Tata Bahasa dan Kanji tingkat Menengah.Terhadap pertanyaan terbuka pertama ini beberapa responden mengatakan kreatifitas mereka untuk membangun pemahaman makna kanji menjadi terasah dengan memanfaatkan beberapa strategi yang diajarkan pada SILK melalui e-learning. Beberapa responden lain juga mengatakan belajar menjadi tidak terikat tempat dan waktu karena bahkan dalam perjalananpun mereka dapat membuka e-learning melalui android atau telepon genggam lainnya.

Pertanyaan jawaban terbuka kedua adalah kendalakendala apa yang dihadapi ketika menggunakan media e-learning ( jawaban terbuka ). Mengenai pertanyaan ini beberapa responden mengatakan meski e-learning dinilai efektif untuk membantu latihan Tata Bahasa Jepang dan Kanji tingkat menengah, pada lokasi-lokasi tertentu saat sinyal sulit diperoleh di daerah tersebut, penugasan ini justru menghambat proses interaksi dengan dosen atau pembelajar lain.

\section{KESIMPULAN DAN SARAN}

\section{Hasil Angket Evaluasi Penggunaan e-learning dan Wawancara Lanjutan}

Penelitian ini adalah penelitian tentang pemanfaatan e-learning unutk latihan Tata Bahasa Jepang dan Kanji tingkat menengah . Melalui metode tindakan kelas dengan menggunakan alat ukur tes awal dan tes akhir serta angket skala likert 5 untuk mengevaluasi efektifitas pemanfaatan $e$ learning untuk kebutuhan tersebut, hasil penelitian ini dapat disimpulkan seperti di bawah ini.

Pertama tentang pengaruh penggunaan e-learning terhadap hasil belajar siswa. Penggunaan media $e$ learning untuk latihan Tata Bahasa dan Kanji tingkat menengah terbukti memberikan pengaruh pada hasil belajar responden. Pengaruh yang lebih signifikan mungkin akan dapat terlihat jika materi 
tes dibatasi hanya terdiri dari materi-materi yang dipelajari dengan bantuan media e-learning.

Kedua, penggunaan e-learning untuk latihan Tata Bahasa dan Kanji tingkat menengah dinilai efektif untuk membantu menguasai pemahaman dasar tentang setiap Kanji. Kemudian, juga dianggap efektif untuk membantu kemandirian pembelajar dalam mengembangkan kemampuan Tata Bahasa dan Kanji tingkat menengah.

Ketiga, di sisi lain penggunaan e-learning dianggap tidak efektif untuk mendapatkan umpan balik dari pengajar,berinteraksi dengan pengajar atau pembelajar lain jika media chatting online yang ada di e-learning tidak dimanfaatkan. Untuk itu, pengajar dapat memanfaatkan media chatting online ini sehingga jika pembelajar ingin bertanya dapat langsung berinteraksi dengan pengajar.

\section{Kelemahan dan Saran}

Ada beberapa hal yang disadari sebagai kelemahan penelitian ini. Pertama, jumlah responden penelitian ini relatif sedikit sehingga data penelitian tidak bisa diolah dengan software statistic seperti SPSS. Jumlah pembelajar yang lulus ke tingkat menengah sedikit sehingga tidak memungkinkan mengambil data lebih banyak lagi. Untuk penelitian lanjutan, ada baiknya jumlah responden ditambah dengan melakukan penelitian bersama dengan dosen di kampus lain sehingga dapat memenuhi jumlah responden yang ideal untuk data penelitian.

Kelemahan yang kedua yaitu, materi tes akhir tidak hanya mencakup materi yang dilatihkan dengan $e$ learning, tetapi juga termasuk materi yang telah dipelajari sebelum tes akhir sehingga pengaruh yang signifikan belum terlalu terlihat. Untuk penelitian berikutnya sebaiknya materi penelitian benar-benar dibatasi pada materi yang dilatihkan dengan e-learning saja.

\section{DAFTAR PUSTAKA}

[1] J.Froyd, N.Simpson, Student-Centered Learning Addressing Faculty Question about StudentCentered Learning,Texas A\&M University ,http://ccliconference.org/files/2010/03/ Froyd_Stu-CenteredLearning.pdf,2010. (diakses pada 15 Juli 2013 pukul 20.00 WIB)

[2] L.Jones, The Student-Centered Classroom, Cambridge University Press, New York, 2007

[3] D. Shinozaki, Constructing The Blendid Learning Model and Examining Its Effectiveness by Employing Moodle - Improving in the BL Model of Advanced Grammar Course in Japanese as Second Language - ,Jounal of Japanese Language Education Methods Vo.18 no.1, 2005.

[4] C. Kano, Intermediate Kanji volume 1, Bonjinsha Press, Tokyo, 1993.

[5] N. Oyanagi, New Approach Japanese Intermediate Course, Nihongo Kenkyusha, Tokyo, 2002. 